re-established on areas previously devastated by the disease.

Capsids of four genera attacking cacao in West Africa are being given close attention, and their lifehistory, mode of nutrition, population fluctuation, and destructive effects studied. It appears from comprehensive studies that the several capsids are in the course of changing from their indigenous host plants to cacao. Spraying of young trees with nicotine sulphate has given good protection, but the method is not economic.

Soil surveys so far undertaken have shown that the incidence of virus disease or capsid pests is apparently not dependent on soil type. A preliminary general soil survey of the Gold Coast, Togo, Nigeria, and the British Cameroons has been completed, and the principal soils identified and their distribution roughly estimated. Further detailed surveys are in progress and much valuable information along several lines is being accumulated.

The reports also give accounts of the work on experimental plots in native farms, and of relevant botanical, horticultural, mycological and physiological studies.

The Director and his staff are to be congratulated on their judiciously balanced programme of fundamental and applied research, and on the progress which they have been able to report on so many interesting lines of work.<smiles>[H]</smiles>

\section{DUST AND HEALTH}

CECTION V of the Conference on "Dust in Industry" arranged at Leeds by the Society of Chemical Industry met on September 30, under the chairmanship of Prof. W. ${ }^{\mathrm{C}}$. Dodds, in the main lecture theatre of the enemical Department of the University.

The large ettendance at this setion indicated the keanness of tho audion for this particular branch of hest th hazards, althdugh good attendance was the rule throughout all the sections.

Unfortunately Prof. R. R. Fabre, dean of the Faculty of Pharmacy in the University of Paris, was unable to be present to read his paper on "Pulmonary Penetration by Toxic Products of Industry" ; but the other five communications were presented and were discussed at some length.

The first paper, by Prof. W. M. Cumming and Dr. I. A. Brownlie, was called "Tetryl Dermatitis and its Prevention". Prof. Cumming gave a review of the problem of tetryl dermatitis, which at one period proved a very serious obstacle to munition production during the War. As was pointed out, tetryl is profoundly altered in constitution by exposure to ultra-violet light, and it is only on the exposed ares of the skin that the dermatitis appears. $\mathrm{He}$ therefore developed the interesting theory that the dermatitis was produced by the products of ultra. violet radiation actually produced over the areas of skin exposed to sunlight. Fie also demonstrated that these products of irradiation could combine with proteins, and it might well be that these protein complexes produced immunity reactions which were responsible for the actual dermatitis. The paper perented an ingenious attempt to bring real experimental method into the study of this very difficult subject, and the consensus of opinion at the end of the discussion was that Prof. Cumming had certainly indicated a valuable new line of approach.
This was followed by a brief paper on the subject of barrier creams. In this it was pointed out that the constituents of a barrier should be very carefully studied to see whether the particular toxic agent against which they are to form a barrior is soluble in them. The lecturer pointed out that in a number of barrier creams the constituents were actually good solvents for the toxic agents, and therefore actually assisted the penetration rather than inhibited it.

Prof. E. J. King gave a masterly summary of the present position of the study and treatment of silicosis. He described in detail the modern treatment, consisting of inhalation of aluminium powder. This again provoked an interesting discussion as to the possible danger of aluminium itself as a toxic agent.

A paper by Dr. T. A. Lloyd-Davies described the high incidence of pulmonary infections in permanganate plants. Dr. Lloyd-Davies provided evidence which supported the view that the lesion, a pneumonitis, is caused by manganese inhalation.

A very interesting review of the arsenical dusts in industry, prepared by Dr. A. N. Currie, but presented by Dr. Buchanan, showed that, despite its sinister reputation, arsenic is not responsible for frequent damage to health in industry. The question of arsenic as a cause of cutaneous cancer was carefully reviewed and discussed.

The final paper in this session was one by Prof. A. L. Roberts, on a method for determining free silica in dusts. This is a very elaborate technique for the determination of particulate crystalline silica.

The interest in industrial medicine in Great Britain was clearly demonstrated by the large attendance at this meeting, and by the really high quality of the discussion which took place at the end. It was interesting to note the complete fusion of interests of the medical workers, experimental biological workers and the actual chemists, engineers and mining engineers who operate the industries in question. There can be no doubt that the Society of Chemical Industry performed a very useful function in arranging this Conference, and it was the unanimous wish that others on the same lines should be arranged.

\section{* FORTHCOMING EVENTS (Meetings marked with an asterisk * are open to the public) \\ Monday, January 17}

RoYal Geographical Society (at Kensington Gore, London, S.W.7), at 8.15 p.m 1 Mr. Francis Huxley: "The Oxford Expedition

to Gambia Colony"

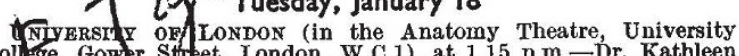
Collye, fower Sty ct, I.ondon, W.C.1), at 1.15 p.m.-Dr. Kathleen

ROYAL SOCIETY of ARTS, DoMmions AND Colonies SECTION (at John Adam Street, Adelphi, London, W.C.2), at 2.30 p.m. -Mr. W. E. F. Ward: "Mass Education in the Colonies".

UNIVERSITY of LONDON (in the Physiology Theatre, University College, Gower Street, London, W.C.1), at 5.15 p.m.- Dr. E. Ashworth Underwood: "The Development of Modern Physiology, $1700-1900^{\prime *}$ (Further Lectures on January 25, February 1 and February 8.)

INSTITUTION OF EleOTRICAL ENGINEERS, RADIO SECTION (at Savoy Place, Victoria Embankment, London, W.C.2), at 5.30 p.m. - Discussion on "Should British Universities consider the Establishment opecial Degrees in Radio ?" (to be opened by Prof. Conway Discussion CIRcle (in the Library, Conway Hall, Red Lion Square, London, W.C.1), at 7 p.m.-Mr. Hector Hawton : "Discussion on Marxism and Intellectual Freedom"."

SOCIETY of CHEMTCAL INDUSTRY, FINE CHEMICALS GROUP (in the large Anatomy Lecture Theatre, King's College, Strand, London, W.C.2), at 7 p.m.-Discussion on "The Approach to the Chemotherapy of Tuberculosis" (to be opened by Dr. James Walker and Dr. P. M. D'A rey Hart). 